\title{
Assess the Climate Readiness of Anantapur Farmers towards Climate Resilient Agriculture Technologies
}

\author{
T. Archana ${ }^{1 *}$, V.Sudha Rani ${ }^{1}$, K. Nagasree $^{2}$ and K.B. Suneetha Devi ${ }^{3}$ \\ ${ }^{1}$ Department of Agriculture Extension, College of Agriculture, PJTSAU, \\ Rajendrangar, Hyderabad.500030, Telangana, India \\ ${ }^{2}$ Department of Agriculture Extension, CRIDA, Santhosh Nagar, Hyderabad.500030, \\ Telangana, India \\ ${ }^{3}$ Department of Agronomy, College of Agriculture, PJTSAU, Rajendrangar, Hyderabad.500030, \\ Telangana, India \\ *Corresponding author
}

\section{A B S T R A C T}

\section{Keywords}

Climate readiness. Climate resilient Agriculture technologies.

Article Info

Accepted:

10 July 2017

Available Online:

10 September 2017
Out of an estimated 143 million hectares of cultivated area in India about 24 per cent is under Dryland agriculture. Rainfed agriculture occupies a prominent place in Indian economy and rural livelihoods. To overcome the drought community farmers have to be ready to adopt climate resilient agriculture technologies. Climate readiness is "the extent to which a respondent is ready to face the effects of climate change especially drought. Keeping this in view, an attempt has been made to assess the climate readiness level of the drought prone area farmers of NICRA adopted villages and non-adopted villages of Singanamala mandal of Anantapur district. The study revealed that majority of NICRA adopted village farmers had high climate readiness, whereas in non NICRA village farmers had medium climate readiness.

\section{Introduction}

Agricultural productivity in rainfed areas continues to remain low and unstable due to weather aberrations, nutrient disorder and poor socio-economic status of farmers. Recurrent droughts undermine the food, fodder and livelihood security of the rural mass and force them to migrate in search of work. Rainfall is the key variable influencing crop productivity in rainfed farming. Intermittent and prolonged droughts are a major cause of yield reduction in most crops.
Long term data for India indicates that rainfed areas witness 3-4 drought years in every 10year period. To overcome the drought community farmers have to be ready to adopt climate resilient agriculture technologies. Climate readiness is "the extent to which a respondent is ready to face the effects of climate change especially drought. Several improved agricultural practices evolved overcome for diverse agro-ecological regions in India have potential to enhance climate 
change adaptation, if deployed prudently. The Government of India has accorded high priority to $\mathrm{R} \& \mathrm{D}$ for coping with climate change in agriculture sector. The Prime Minister's National Action Plan on Climate Change has identified agriculture as one of the eight National Missions. Indian Council of Agricultural Research (1CAR), New Delhi has launched a major network project entitled, National Initiative on Climate Resilient Agriculture (NICRA) during 2010-11, focusing on the process of developing district level contingency plans for all the rural districts of country with Central Research Institute for Dryland Agriculture (CRIDA), Hyderabad as the nodal agency with an outlay of Rs.350 crores for the XI Plan. The project is being implemented at large number of research institutes of ICAR, State Agricultural Universities and $100 \mathrm{KVKs}$. Keeping this in view, an attempt has been made to assess the climate readiness level of the drought prone area farmers of NICRA adopted villages and non-adopted villages of Singanamala mandal of Anantapur district.

\section{Materials and Methods}

The States of Andhra Pradesh was selected purposively for the study. As the investigator was familiar with the local language, which would help to build up quick rapport and also enable in-depth study combined with personal observation. Anantapur district from the Andhra Pradesh was selected purposively. Singanamala mandals was purposively selected from the district for the study. Four villages were selected purposively from mandal. Two NICRA adopted villages and two non NICRA villages were selected from one mandal. 30 farmers from each village were selected at random to make a total sample of 60 respondents from NICRA villages and 60 respondents from non NICRA villages. For measuring climate readiness of the farmers, 10 statements were included in the schedule. For all the statements included in this variable, respondent's responses were elicited on a four point continuum of always, sometimes, rarely and never. A score of three, two, one and zero were assigned these categories respectively. Then the respondents were grouped into five categories of very low, low, medium, high and very high based on the inclusive class interval technique. The results were expressed in the form of frequencies and percentages.

\section{Results and Discussion}

It could be inferred from the table 1 that, majority $(70.00 \%)$ of the NICRA farmers of Ananthapur district had high followed by medium (20.00\%), low (8.33\%) and very low (1.67\%). While in Ananthapur non NICRA majority $(55.00 \%)$ of farmers had medium followed by low $(38.33 \%)$, similar portion of respondents had high $(3.33 \%)$ and very low $(3.33 \%)$ and none of them found to be very high.

Level of climate readiness of the two groups of farmers was studied based on administration of ten predetermined statements reflecting climate resilience. The analysis has given a clear cut difference between the two groups both NICRA and non NICRA based on their readiness level. The results revealed that majority of NICRA respondents had high climate readiness. The probable reason for this NICRA farmers were ready to follow contingency crop planning, rain water harvesting structures on their field, soil moisture conservation practices, farming systems and engage in non-farm activities. And also in NICRA villages watershed activities and NAREGA activities were done. These NICRA farmers attended trainings of NICRA through KVK, whereas in non NICRA farmers of the majority of the farmers had medium climate readiness followed by low. 
Table.1 Distribution of respondents according to their climate readiness

\begin{tabular}{|c|c|c|c|c|c|}
\hline \multirow{4}{*}{$\begin{array}{l}\text { S. } \\
\text { No. }\end{array}$} & \multicolumn{5}{|c|}{ Climate Readiness } \\
\hline & \multirow{3}{*}{ NRM } & \multicolumn{4}{|c|}{ Ananthapur } \\
\hline & & \multicolumn{2}{|c|}{$\begin{array}{l}\text { NICRA farmers } \\
\qquad(n=60)\end{array}$} & \multicolumn{2}{|c|}{$\begin{array}{c}\text { Non NICRA } \\
\text { farmers }(n=60)\end{array}$} \\
\hline & & $\mathbf{F}$ & $\%$ & $\mathbf{F}$ & $\%$ \\
\hline 1 & Very Low (5-11) & 1 & 1.67 & 2 & 3.33 \\
\hline 2 & Low (12-18) & 5 & 8.33 & 23 & 38.33 \\
\hline 3 & Medium (19-25) & 12 & 20.00 & 33 & 55.00 \\
\hline 4 & High (26-32) & 42 & 70.00 & 2 & 3.33 \\
\hline 5 & Very High (33-39) & 0 & 0.00 & 0 & 0.00 \\
\hline & Total & 60 & 100 & 60 & 100 \\
\hline
\end{tabular}

The probable reason for this in Ananthapur non NICRA farmers were ready to follow the NRM technologies, farmers dug out the 100 farm ponds for each village through NREGA and providing 100 days wage employment to them in lean period, check dam construction and excavating trenches on hill side areas through IWMP but there were no renovations for the soil moisture conservation practices by the farmers. Hence, the Department of Agriculture may gear up the efforts to pass on, standardised, valid and reliable technical information to the farmers through training programmes, group discussions, field visits etc., a kind of team spirit also inculcated among the farmers to accrue the benefits of collective decision making and to follow group action to practice the climate resilient agriculture techniques for effective climate readiness.

Majority of NICRA respondents had high climate readiness, whereas in non NICRA the majority of the farmers had medium climate readiness. NICRA farmers were motivated highly for climate readiness to face the drought because the farmers were attended more number of trainings, involved in more extension activities and did more community based natural resource management activities than the non NICRA farmers. To get more resilient to drought climate readiness is the necessary action has to be taken by the community farmers.

\section{References}

Hussain, R., Dutta, K.K., Tamuly, D., Deka, R. L and Khanikar, P.G. 2013. Farmers' perception of climate change impact and its mitigation in Golaghat district of Assam. Journal of Agrometeorology. 15 (2): 203-208.

IPCC. 2001. Climate change 2001: impacts, adaptation and vulnerability. Intergovernmental panel on climate change. Cambridge, UK: Cambridge University Press.

IPCC. 2012. Managing the risks of extreme events and disasters to advance climate change adaptation summary for policymakers, special report of governmental panel on climate change. Accessed on $14^{\text {th }}$ March 2015.

Joyce, L.A., Blate, G.M., McNulty, S.G., Millar, C.I., Moser, S., Neilson, R.P and Peterson, D.L. 2009. Managing for multiple resources under climate change: National Forests. Environmental Management. 44: 10221032.

Maddison, D., 2006. The perception and adaptation to climate change in Africa. CEEPA Discussion Paper No. 10. 
Centre for Environmental Economics and Policy in Africa, University of Pretoria, South Africa.

Sarkar Sujit, 2014. Climate change vulnerability and adaptive behavior of farmers Himalayan and arid ecosysytems. Ph.D. Thesis. Indian Agricultural Research Institute. New Delhi.

\section{How to cite this article:}

Archana, T., V. Sudha Rani, K. Nagasree and Suneetha Devi, K.B. 2017. Assess the Climate Readiness of Anantapur Farmers towards Climate Resilient Agriculture Technologies. Int.J.Curr.Microbiol.App.Sci. 6(9): 3694-3697. doi: https://doi.org/10.20546/ijcmas.2017.609.455 